\title{
Economics
}

2019; 8(3): 106-113

http://www.sciencepublishinggroup.com/j/eco

doi: $10.11648 /$ j.eco.20190803.13

ISSN: 2376-659X (Print); ISSN: 2376-6603 (Online)

\section{Evaluation of the Impact of Various Doha Round Conclusion Scenarios at the WTO Agricultural Negotiation}

\author{
Kone Siaka $^{1, \text { * }}$, Noufou Coulibaly ${ }^{1}$, Yapi Yapo Magloire², Djina Djolo Jean Marc Junior ${ }^{1}$ \\ ${ }^{1}$ Management and Applied Economics Department, National Polytechnic Institute Houphouet Boigny, Yamoussoukro, Cote d'Ivoire \\ ${ }^{2}$ Agriculture and Animal Science Department, National Polytechnic Institute Houphouet Boigny, Yamoussoukro, Cote d'Ivoire
}

Email address:

ksiakawole@gmail.com (K. Siaka)

${ }^{*}$ Corresponding author

To cite this article:

Kone Siaka, Noufou Coulibaly, Yapi Yapo Magloire, Djina Djolo Jean Marc Junior. Evaluation of the Impact of Various Doha Round Conclusion Scenarios at the WTO Agricultural Negotiation. Economics. Vol. 8, No. 3, 2019, pp. 106-113. doi: 10.11648/j.eco.20190803.13

Received: July 28, 2019; Accepted: August 29, 2019; Published: September 19, 2019

\begin{abstract}
This paper evaluates the impacts of various scenarios proposed in the context of the WTO Doha Round agricultural negotiations and a new scenario that considers differential treatment for developing countries. The objective of this paper is to contribute to find the desired consensus among WTO members to facilitate trade and avoid trade wars. We used the Agricultural Trade Policy Simulation Model (ATPSM) to measure impacts and use the ADAMS model to measure the equity of the various scenarios. We considered seven negotiating scenarios (1) Uruguay Round Agreement, (2) C4 country proposal, (3) EU proposal, (4) USA proposal, (6) our proposal and (7) full liberalization of trade. The results showed that our proposal increases the cotton producers' price by $10.8 \%$, better than the $\mathrm{C} 4$ countries proposal $(9.0 \%)$ and USA proposals (6.1\%). Our proposal for agricultural agreements increases the world price (8.1\%), the consumer's price (7.4\%) and the volume of exports (2.3\%), certainly to a lesser degree than that of the $\mathrm{C} 4$ countries proposal but more than the USA proposal. In terms of the equity criterion, it is as favorable as the other scenarios compared to the status quo of the Uruguay Round. Our proposal presents the elements for a compromise to conclude the Doha Round, with benefits for developing countries and the introduction of a new mechanism of international solidarity.
\end{abstract}

Keywords: Agriculture Agreements, International Trade, Cotton, Doha Development Round, Equity, WTO

\section{Introduction}

Launched in 2001, the WTO Doha Development Round has not yet been concluded. In particular, he stumbles over the agricultural aspect, where the cotton issue has taken a particular importance. By its complaint in 2002, Brazil has condemned US subsidies on cotton. The WTO Dispute Settlement Body (DSB) on August 31, 2009, sentenced the US to pay Brazil $\$ 800$ million in damages for the year 2009, Brazil has agreed to suspend its retaliatory measures following a bilateral agreement with the United States.

Four African countries (Benin, Burkina Faso, Mali and Chad) or the $\mathrm{C} 4$ group introduced the sectoral cotton initiative at the WTO Ministerial Meeting in Cancun in September 2003 to demand total elimination of subsidies on cotton. This initiative led to the creation, on 19 September 2004, of the WTO Cotton Subcommittee and its commitment at the Hong Kong Ministerial Conference in 2005, to address cotton ambitiously, expeditiously and specifically in the context of the agriculture negotiations based on three pillars (market access, domestic support and export competition). However, until today, this commitment is not realized.

The difficulties of concluding the Doha Round reflect a change in the attitude of emerging and developing countries to take a more active part in the negotiations to protect their interests, as opposed to their passivity in the Round. of Uruguay. The projected impacts of this latter Round may explain the change in attitude of developing countries. The gains of liberalization for some nations are weak or even negative in a context of imperfect competition [1]. Indeed, in Doha round, the nations of the world had agreed on a new round of negotiations to redress some imbalances, with the general impression that previous rounds of negotiations had benefited the wealthiest nations at the expense of poorer. In 
April 2011, then the WTO Director-General Pascal Lamy "asked members to think hard about 'the consequences of throwing away ten years of solid multilateral work. "Although considerable time and effort has been spent on issues such as agriculture, a key focus of the Doha Round is development [2].

Since the WTO's commitment to deal specifically and ambitiously with cotton, several proposals for agricultural agreements have been advanced by WTO member countries, but differences between countries remain. We have identified four proposed agreements: a) the WTO negotiating text, Falconner, submitted in December 2008, b) the C4 countries proposal, c) European Union proposal and d) the USA proposal. As a reference, the standstill scenario (continuation of measures since the Uruguay Round agreement) and the full trade liberalization scenario.

The current stalemate in the negotiations demonstrates the relevance of proposing new scenarios that take the interests of developing countries more into account, including the principle of special and differential treatment [3]. The principle of special differential treatment offers opportunities to better respond to the problems of many developing countries. The objective of this paper is to propose an original scenario, evaluate and compare its impacts with the current scenarios in order to show that it can constitute a compromise to close negotiations on the agricultural aspect. The comparison is made according to the classic criteria of variation of prices, volumes and well-being, but also according to an additional criterion of equity.

We have organized this paper into three sections. The first section deals with methodology and analysis data. The second section presents the results and discussions of various agricultural agreement scenarios. The third section concludes.

\section{Methodology}

\subsection{Agricultural Trade Simulation Model (ATPSM)}

We measured the economic impacts of the seven agricultural agreement simulation scenarios in the Doha Round with the Agricultural Trade Simulation Model (ATPSM). The ATPSM model was developed jointly by the Food and Agriculture Organization (FAO) and the United Nations Conference on Trade and Development (UNCTAD). It is a model of partial equilibrium, comparative, static, multi-products (35 including cotton), multi-region (161 countries). The ATPSM was designed to measure the impact of the reduction of distortionary measures on the three pillars of the WTO agricultural negotiations (market access, export competition and domestic support).

We have extended the scope of the ATPSM model by considering the case of an increase in distorting support by developing countries (scenario 6) under the special differential treatment allowed in the WTO [4]. All trade policies (taxes, export subsidies and domestic support) are defined in ad valorem equivalents. We have updated the database (tariffs, quota and amount of support) with the notifications available on the WTO website.

\subsection{Equity Measurement}

The measurement of the "effort function" of reducing tradedistorting support by WTO member States is one of the original features of our analysis. To our knowledge, this approach has not yet been considered in the work carried out so far. "There is inequity for a person whenever the ratio of his or her remuneration (output) and contributions (input) compared to what he or she receives from the ratio of remuneration (output) and contributions (input) of others is unequal. As soon as two individuals exchange something, it is possible that one of them considers that the exchange is unfair" [5]. The effort function (E) is calculated as follows [6]:

$$
\mathrm{E} \cdot \mathrm{SA}=\mathrm{SA}^{*}
$$

SA: real level of support to be reduced.

SA*: "de minimis'level of support allowed.

Two cases may arise: if actual support is higher than the authorized support, WTO Member States will have to make efforts to reduce it to at least the authorized level (SA*), but if actual support is less than or equal to the authorized support, Member States will have made maximum efforts to reduce prohibited support and the effort function will take on the value 1. The "effort function" for reducing distortionary supports is:

$$
\text { Reduction effort }\left\{\begin{array}{l}
E=\min \left(\frac{S A^{*}}{S A}, 1\right) \forall \mathrm{SA} \neq 0 \\
E=1 \text { if } S A=0
\end{array}\right.
$$

Two countries $i$ and $j$ members of the WTO, we compared the inequity ratios: for each simulation scenario:

$$
\begin{aligned}
R_{i} & =\frac{E_{i}}{\text { Gains }_{i}} \\
R_{i} & =\frac{E_{j}}{\text { Gains }_{j}}
\end{aligned}
$$

Gains: Profit of a WTO member country from trade

Equations (3) and (4) identified the most equitable simulation scenario for all WTO members. The most equitable scenario is the one that allows the least variability in equity ratios [7].

\subsection{Modalities of the Simulation Scenarios for the Doha Round Negotiations}

The seven (07) simulation scenarios correspond, to the Uruguay Round Agreement (AUR), to Falconner's text of December 2008 (see document TN / AG / W / 4 / Rev. 4), to the proposal of $\mathrm{C} 4$ (group of four African countries: Benin, Burkina Faso, Mali and Chad) (see document TN / AG / SCC / GEN / 4), to the proposal of the European Union, to the proposal of the States United States, to our proposal for agricultural agreements and, finally, to a proposal for full liberalization. Each of these proposals addresses the three pillars of the WTO agricultural negotiations: market access, export competition and domestic support. 
Market access. The Uruguay round agreement proposes a reduction of $36 \%$ for developed countries (DVD), of $24 \%$ for developing countries (DC) and of $0 \%$ for Least-developed countries (LDCs). The text of Falconner 2008 proposes a formula of staggered reduction of tariffs: for DVD, when the tariff is lower than $20 \%$ it is reduced by $50 \%$, if it is between 20 and $50 \%$ it is reduced by $57 \%$, if it is between 50 and $75 \%$ it is reduced by $64 \%$ and if it is greater than $75 \%$ it is reduced by $70 \%$. For DC, when the tariff is lower than $30 \%$ it is reduced by $34 \%$, if it is between 30 and $80 \%$ it is reduced by $38 \%$, if it is between 80 and $130 \%$ it is reduced by $43 \%$ and if it is greater than $130 \%$ it is reduced by $47 \%$. The $\mathrm{C} 4$ group proposes to reduce tariffs on cotton from by $100 \%$ for DVD and DC, and $0 \%$ for LDCs. The European Union proposes to reduce them by $36 \%$ for DVD and DC, and $0 \%$ for LDCs. The USA proposes to reduce them by $75 \%$ for DVD and DC, and $0 \%$ for LDCs. Our proposal suggests reducing them by $100 \%$ for DVD, by $80 \%$ for DC, by $85 \%$ for China and by $0 \%$ for LDCs for cotton. Finally, the full liberalization scenario is to remove all taxes for all the countries.

Export competition. The Uruguay Round agreement proposes to reduce export subsidies by $36 \%$ for DVD, by $24 \%$ for DC and by $0 \%$ for LDCs. The European Union proposes to reduce them by $45 \%$ for DVD, by $30 \%$ for DC and by $0 \%$ for LDCs. The text of Falconner 2008, the C4 countries proposal, the USA proposal and our proposal suggest reducing export subsidies by $100 \%$ for DVD and DC and by $0 \%$ for LDCs. Finally, total liberalization consists of abolishing all export subsidies for all countries.

Domestic support. The Uruguay round agreement proposes a reduction of $20 \%$ for DVD, of $14 \%$ for DC and of $0 \%$ for LDCs. The Falconner 2008 text proposes a tiered tariff reduction formula: for DVD, when the overall support measure (AMS) is less than US \$ 15 billion, the AMS is reduced by $45 \%$, if the AMS is between 15 and 40 billion US dollars, it is reduced by $60 \%$, if the AMS is greater than 40 billion US dollars, it is reduced by $70 \%$. For DC, the AMS is reduced by $30 \%$ and by $0 \%$ for LDCs. The $\mathrm{C} 4$ countries proposes a tiered tariff reduction formula: for DVD, when the overall support measure (AMS) is less than US \$ 15 billion, the AMS is reduced by $86 \%$, if the AMS is between 15 and 40 billion US dollars, it is reduced by $83 \%$, if the AMS is greater than 40 billion US dollars it is reduced by $85 \%$. For DC, the AMS is reduced by $30 \%$ and by $0 \%$ for LDCs. The European Union proposes to reduce the AMS by $65 \%$ for DVD, by $43 \%$ for DC, and by $0 \%$ for LDCs. The USA proposes to reduce AMS by $60 \%$ for DVD, by $30 \%$ for DC and by $0 \%$ for LDCs. Our proposal is to reduce the AMS by $73 \%$ for DVD, by $30 \%$ for DC, by $0 \%$ for LDCs and increase the de minimis level to $50 \%$ of the value of production in the West and Central African countries. Finally, total liberalization means eliminating all internal support for all countries.

\section{Results}

\subsection{Impact on Prices}

The proposals of the agricultural agreements in the WTO negotiations improve the world price of cotton compared to the Uruguay Round agreement (Table 1).

Table 1. Impacts of seven agricultural agreement scenarios on prices as a percentage change.

\begin{tabular}{llll}
\hline Scenarios & World Price & $\begin{array}{l}\text { Producer's } \\
\text { Prices }\end{array}$ & $\begin{array}{l}\text { Consumer's } \\
\text { Prices }\end{array}$ \\
\hline AUR & 2.0 & 1.7 & 1.9 \\
Falconner 2008 & 5.1 & 4.5 & 4.9 \\
Falco_C4 & 11.1 & 9.0 & 9.2 \\
EU & 4.0 & 3.3 & 3.9 \\
USA & 7.1 & 6.1 & 6.5 \\
Prop_Alter. & 8.1 & 10.8 & 7.4 \\
Lib_tot. & 12.3 & 9.5 & 9.5 \\
\hline
\end{tabular}

AUR: Uruguay Round Agreements, EU: European Union, Falconner 2008: text of Falconner agricultural agreements of July 2008 without cotton specificity, USA: United States of America, Prop_Alter. Our proposal for Doha Round agricultural agreements, Falco_C4: text of Falconner agricultural agreements of July 2008 accepting the position of the C4, Lib_tot. scenario of total liberalization.

Source: results of ATPSM model simulations.

The world price of cotton has increased for all simulation scenario (Table 1). The world price of cotton varied from $2.0 \%$ to $12.3 \%$ respectively for the Uruguay Round agreement and the situation of total liberalization. The world price varied by $7.1 \%$ on average for all scenarios. The proposal of $\mathrm{C} 4$ countries has a price effect of $11.1 \%$. The impacts of the agreement scenarios are all greater than the impact of the Uruguay Round Agreement.

All scenarios increase the price to cotton producers in the C4 countries, and it is our proposals that increase this price the most. The average price to producers has increased regardless of the proposal for agricultural agreements in the Doha Round (Table 1). The producer price varies from $1.7 \%$ to $10.8 \%$, respectively for the Uruguay Round Agricultural Agreement (AUR) and our proposal. Against an average increase of $6.4 \%$, for all scenarios, the producer's prices decrease in USA and in EU.

Regardless of the scenario simulating the agricultural agreements, the average price to cotton consumers has increased (Table 1). The average price to cotton consumers increased from $1.9 \%$ to $9.5 \%$ respectively for the Uruguay Round agreement and the simulation of full liberalization. The price to cotton consumers varies by $6.2 \%$ on average for all simulation scenarios. Our proposal for agricultural agreements increases the price to consumers by $7.4 \%$ and falls between the US and C4 proposals.

For all scenarios, the average consumer's prices of cotton increased (Table 1). The average cotton consumer's prices increased from $1.9 \%$ to $9.5 \%$ respectively for the Uruguay Round agreement and the full liberalization. The cotton consumer's prices vary by $6.2 \%$ on average for all simulation scenarios. Our proposal raises cotton consumer's prices by $7.4 \%$ and lies between the USA and C4 countries proposals. 


\subsection{Impact on Volumes (Production)}

The full liberalization scenario, the Falconner proposal, the USA proposal, our proposal and the $\mathrm{C} 4$ countries proposal increase the volume of exports, as opposed to the EU proposal and AUR scenarios. The proposal for full liberalization leads to an increase in export volume of $3.6 \%$. The increase in exports is highest with the full liberalization scenario (3.6\%), slightly exceeding the $\mathrm{C} 4$ countries scenario. The increase in exports resulting from our proposals $(2.3 \%)$ is intermediate and significantly higher than that of Falconner proposal.

The effects of different simulation scenarios on production are low. World cotton production varies from $-0.4 \%$ to $0.079 \%$ depending on the scenarios. Only the $\mathrm{C} 4$ countries proposal increases world cotton production.

\subsection{Impact on Expenditure, Government Revenue and Trade Balance}

All scenarios lead a reduction of domestic support expenditures estimated at $\$ 4,358.81$ million globally (Table 2 ). For the initial situation (without any reduction in support), $85.1 \%$ of global domestic support was provided by developed countries compared with $14.9 \%$ for developing countries and $0 \%$ for least developed countries. Apart from the $\mathrm{C} 4$ countries proposals and our proposal, for all other proposals, the share of developed country spending in global support ranges from $84.0 \%$ to $75.0 \%$. With the $\mathrm{C} 4$ countries proposal, the percentage in domestic support is $42.0 \%$ for DVD, $58.0 \%$ for DC and $0 \%$ for LDCs.

For our proposal, the percentage in domestic support is $42.8 \%$ for DVD, $29.4 \%$ for DC and $27.9 \%$ for LDCs. Our proposal increased West and Central Africa (WCA) domestic support from US \$ 0 to US \$ 829.09 million and reduced domestic support for developed countries from US \$ 3,710.85 to US \$ 966 million, \$ 91 million. Our proposal generated an additional \$ 829.09 million for the West and Central African countries and generated an additional gain of $\$ 2,743.94$ million. The additional cost of the West and Central African countries represents $30.2 \%$ of the additional gain made by the developed countries. The rationale behind our proposal is that developed countries must make additional commitments to reduce distortion, which will lead to gains. A share (30.2\%) of these gains can be transferred to the countries of West and Central Africa in return for the damage created for several years. We propose that the economies of the developed countries, because of the reduction of internal support, should be used to feed an international solidarity fund. This solidarity fund will be used to finance emergency programs and assistance to the cotton sector in developing countries, particularly in $\mathrm{C} 4$ countries.

Table 2. Impact of the seven agricultural agreement scenarios on domestic support expenditures in million US dollars.

\begin{tabular}{|c|c|c|c|c|c|c|}
\hline \multirow{2}{*}{ Scenarios } & \multicolumn{6}{|c|}{ Group of countries } \\
\hline & WCA & $\mathrm{C4}$ & DVD & DC & LDCs & WLD \\
\hline Initial & 0 & 0 & 3710.85 & 647.96 & 0 & 4358.82 \\
\hline AUR & 0 & 0 & 2931.71 & 560.73 & 0 & 3492.44 \\
\hline Falconner 2008 & 0 & 0 & 1990.17 & 653.06 & 0 & 2643.23 \\
\hline Falco_C4 & 0 & 0 & 508.83 & 691.03 & 0 & 1199.86 \\
\hline $\mathrm{EU}$ & 0 & 0 & 1214.07 & 376.65 & 0 & 1590.72 \\
\hline USA & 0 & 0 & 1446.43 & 463.79 & 0 & 1910.22 \\
\hline
\end{tabular}

WCA: West and Central Africa, C4: group of four African countries (Benin, Burkina Faso, Mali, and Chad), DVD: Developed countries, DC: Developing countries, LDCs: Least developed countries, WLD: World, AUR: Uruguay Round Agreements, EU: European Union, Falcon 2008: Text of Falconer Agricultural Agreements of July 2008 without cotton specificity, USA: United States of America, Prop_Alter. Alternative proposal for Doha Round agricultural agreements, Falco_C4: text of Falconner agricultural agreements of July 2008 accepting the position of the C4, Lib_tot. scenario of total liberalization.

Source: results of ATPSM model simulations.

Table 3. Impact of the seven agricultural agreement scenarios on public revenues in millions of US dollars.

\begin{tabular}{|c|c|c|c|c|c|c|}
\hline \multirow{2}{*}{ Scenarios } & \multicolumn{6}{|c|}{ Group of countries } \\
\hline & WCA & C4 & DVD & DC & LDCs & WLD \\
\hline AUR & -0.09 & -0.02 & 871.11 & 128.79 & 0.29 & 1000.19 \\
\hline Falconner 2008 & -0.24 & -0.05 & 1968.87 & 130.05 & 1.76 & 2100.67 \\
\hline Falco_C4 & -6.07 & -0.06 & 3446.76 & -335.64 & 4.84 & 3115.97 \\
\hline EU & -0.19 & -0.04 & 2621.40 & 296.36 & 1.25 & 2919.01 \\
\hline USA & -1.75 & -0.06 & 2511.23 & 212.37 & 2.7 & 2726.30 \\
\hline Prop_Alter. & -829.09 & -402.72 & 2988.67 & -30.15 & -626.05 & 2332.47 \\
\hline
\end{tabular}

WCA: West and Central Africa, C4: group of four African countries (Benin, Burkina Faso, Mali, and Chad), DVD: Developed countries, DC: Developing countries, LDCs: Least developed countries, WLD: World, AUR: Uruguay Round Agreements, EU: European Union, Falcon 2008: Text of Falconer Agricultural Agreements of July 2008 without cotton specificity, USA: United States of America, Prop_Alter. Alternative proposal for Doha Round agricultural agreements, Falco_C4: text of Falconner agricultural agreements of July 2008 accepting the position of the C4, Lib_tot. scenario of total liberalization.

Source: results of ATPSM model simulations. 
to US \$ 4,249 million (Table 3). Government revenues in developed countries increased for all scenarios with a maximum increase in government revenue of $\$ 3,955.59$ million for the full liberalization simulation, and a minimum of \$ 871.11 for the Uruguay Agreement round. Government revenues of the least developed countries increased in all scenarios except in the liberalization scenarios and our proposal. Government revenue is falling with our proposal as it suggests additional internal support spending from West and Central African countries, of which 7 are least developed countries. Government revenues increased in all scenarios, except for the $\mathrm{C} 4$ proposal and our proposal. The losses in government revenue are partly explained by the loss of customs revenue due to the reduction of tariffs.

The trade balance is improving for West and Central Africa, the C4 countries and the least developed countries (Table 4). The trade balance of developing countries and developed countries fall. In the model, it is the change in the world price and the tariffs that affect the level of the trade balance. The simulations of the Uruguay Round agricultural agreement, Falconner 2008 and our proposal improve the trade balance of developing countries. The proposal of the $\mathrm{C} 4$ countries, of the USA and total liberalization simulations deteriorate the terms of trade.

Table 4. Impact of the seven agricultural agreement scenarios on the trade balance in millions of US dollars.

\begin{tabular}{|c|c|c|c|c|c|}
\hline \multirow{2}{*}{ Scenarios } & \multicolumn{5}{|c|}{ Group of countries } \\
\hline & WCA & C4 & DVD & DC & LDCs \\
\hline AUR & 30.63 & 18.29 & -50.92 & 20.43 & 27.15 \\
\hline Falconner 2008 & 79.38 & 47.24 & -95.63 & 15.63 & 71.17 \\
\hline Falco_C4 & 175.85 & 105.02 & -31.17 & -151.78 & 162.53 \\
\hline $\mathrm{EU}$ & 62.44 & 37.2 & -280.35 & 217.69 & 55.76 \\
\hline USA & 110.77 & 66.02 & -85.69 & -27.18 & 100.36 \\
\hline Prop_Alter. & 102.57 & 63.64 & -120.5 & 9.25 & 96.67 \\
\hline Lib tot. & 196.47 & 117.8 & -62.64 & -125.78 & 165.32 \\
\hline
\end{tabular}

WCA: West and Central Africa, C4: group of four African countries (Benin, Burkina Faso, Mali, and Chad), DVD: Developed countries, DC: Developing countries, LDCs: Least developed countries, WLD: World, AUR: Uruguay Round Agreements, EU: European Union, Falcon 2008: Text of Falconer Agricultural Agreements of July 2008 without cotton specificity, USA: United States of America, Prop_Alter. Alternative proposal for Doha Round agricultural agreements, Falco_C4: text of Falconner agricultural agreements of July 2008 accepting the position of the C4, Lib_tot. scenario of total liberalization.

Source: results of ATPSM model simulations.

\subsection{Impact on the Producer's Surplus and Well-being}

Producer's surpluses in West and Central Africa, in C4 countries, in developing countries and in least developed countries record gains for all simulation scenarios (Table 5). However, the producer's surplus in developed countries shows losses for all simulations. The reduction in the high level of agricultural support to producers in developed countries causes losses for the producer's surplus because of the cross-cutting effects of lower consumer prices and the level of production. The $\mathrm{C} 4$ countries proposal is the most attractive for the West and Central African countries, the C4 countries and for the least developed countries as this proposal generates the highest producer's surpluses.

For West and Central African countries, the C4 countries, the developed and the least developed countries, all simulations improved overall welfare (Table 6). Aside from Falconner's text, all other simulations have reduced total welfare. Total welfare is falling for developing countries (the sum of consumer surplus losses and government revenues is greater than the earnings of producer's surplus.

Table 5. Impact of the seven agricultural agreement scenarios on the producer's surplus in millions of US dollars.

\begin{tabular}{llllll}
\hline \multirow{2}{*}{ Scenarios } & Group of countries & & & & DC \\
\cline { 2 - 6 } & WCA & C4 & DVD & 155.45 & LDCs \\
\hline AUR & 33.3 & 16.12 & -647.18 & 453.31 & 127.69 \\
Falconner 2008 & 85.57 & 41.44 & -1476.47 & 558.19 & 281.02 \\
Falco_C4 & 184.32 & 91.23 & -2488.93 & 462.73 & 100.73 \\
EU & 67.5 & 32.69 & -2097.25 & 459.8 & 177.83 \\
USA & 118.27 & 57.72 & -1853.95 & 595.2 & 187.52 \\
Prop_Alter. & 114.23 & 55.28 & -2234.70 & 253.73 & 280.27 \\
Lib_tot. & 204.77 & 102.11 & -2898.99 & \\
\hline
\end{tabular}

WCA: West and Central Africa, C4: group of four African countries (Benin, Burkina Faso, Mali, and Chad), DVD: Developed countries, DC: Developing countries, LDCs: Least developed countries, WLD: World, AUR: Uruguay Round Agreements, EU: European Union, Falcon 2008: Text of Falconer Agricultural Agreements of July 2008 without cotton specificity, USA: United States of America, Prop_Alter. Alternative proposal for Doha Round agricultural agreements, Falco_C4: text of Falconner agricultural agreements of July 2008 accepting the position of the C4, Lib_tot. scenario of total liberalization.

Source: results of ATPSM model simulations. 
Table 6. Impact of simulations on total welfare in millions of US dollars.

\begin{tabular}{llllll}
\hline \multirow{2}{*}{ Scenarios } & Group of countries & & & & DC \\
\cline { 2 - 6 } & WCA & C4 & DVD & -10.3 & 2.28 \\
\hline AUR & 15.13 & 11.16 & 141.38 & 28.7 & 7.8 \\
Falconner 2008 & 39.22 & 28.77 & 292.08 & -183.14 & 21.95 \\
Falco_C4 & 88.32 & 63.74 & 430.38 & -81.42 & 5.77 \\
EU & 30.85 & 22.67 & 334.85 & -53.22 & 11.92 \\
USA & 54.98 & 40.15 & 348.44 & -95.89 & 0.5 \\
Prop_Alter. & 45.58 & 37.56 & 386.23 & -208.48 & 25.71 \\
Lib_tot. & 99.58 & 71.52 & 459.31 & \\
\hline
\end{tabular}

WCA: West and Central Africa, C4: group of four African countries (Benin, Burkina Faso, Mali, and Chad), DVD: Developed countries, DC: Developing countries, LDCs: Least developed countries, WLD: World, AUR: Uruguay Round Agreements, EU: European Union, Falcon 2008: Text of Falconer Agricultural Agreements of July 2008 without cotton specificity, USA: United States of America, Prop_Alter. Alternative proposal for Doha Round agricultural agreements, Falco_C4: text of Falconner agricultural agreements of July 2008 accepting the position of the C4, Lib_tot. scenario of total liberalization.

Source: results of ATPSM model simulations.

\subsection{Impact on Equity}

The Doha Round proposals are all more equitable than those of the Uruguay Round except for the Falconner 2008 proposal. The Doha Round subtitled "Development Round" aims to reduce inequalities observed in the implementation of previous cycles. The issue of the fairness of the agreements is important and central to the negotiations. Our results show that the situation of total liberalization is the most equitable position, followed by that of the $\mathrm{C} 4$ countries proposal, the EU, our proposal, the US, the AUR and the text of Falconner 2008 (Figure 1). From the point of view of the equity dimension, it is the $\mathrm{C} 4$ proposal that is the fairest for cotton producers. Our proposal for agreements is, in terms of equity, between the position of the $\mathrm{C} 4$ countries and that of the USA who disagree on the issue of subsidies to cotton producers.

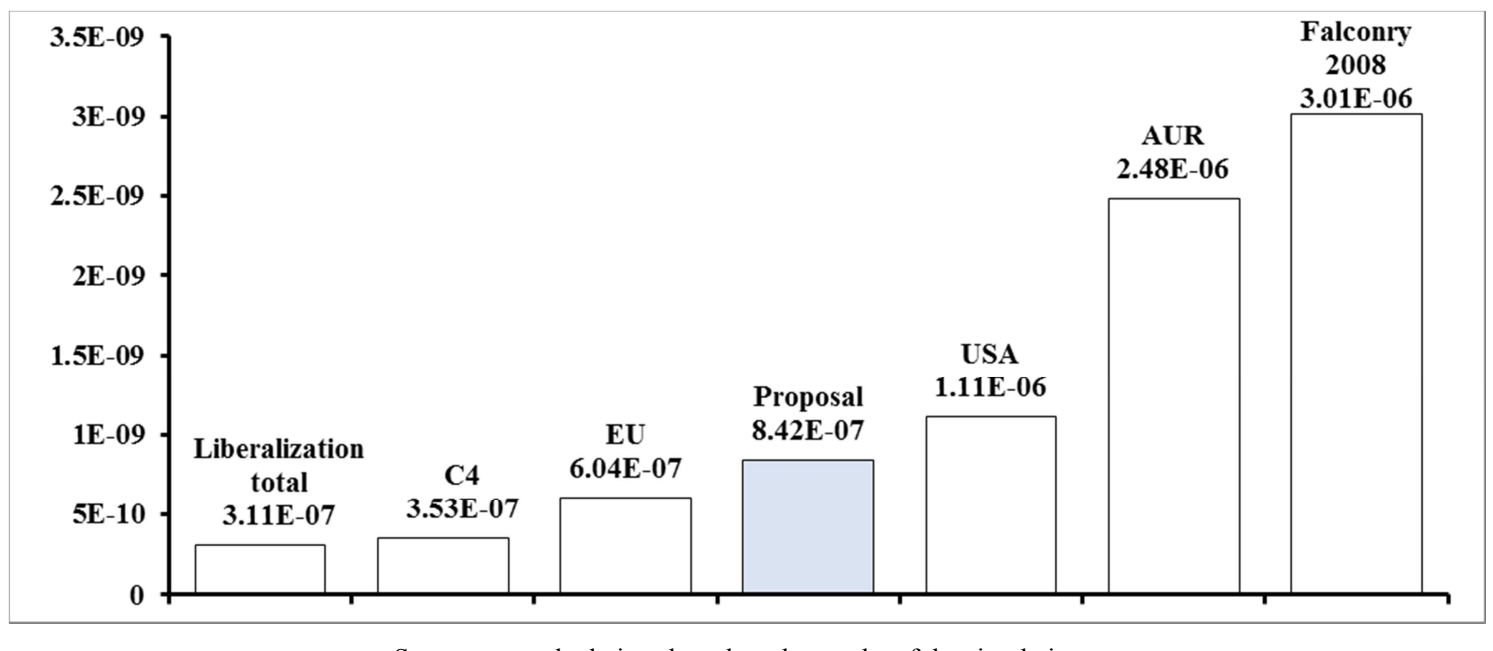

Source: our calculations based on the results of the simulations.

Figure 1. Impact of simulations on Equity ratios.

\section{Discussion}

Our results showed that, the scenarios of full liberalization, of C4 countries (Benin, Burkina Faso, Mali and Chad) proposal, of our proposal, of USA proposal, of Falconner proposal, of EU proposal and the agreement of The Uruguay Round raises the world cotton price by $12.3 \%, 11.1 \%, 8.1 \%$, $7.1 \%, 5.1 \%, 4.0 \%$ and $2.0 \%$ respectively. The scenarios of our proposal, of total liberalization, of C4 countries, of USA proposal, of Falconner, of EU proposal and the Uruguay Round agreement increase the producer price by $10.8 \%, 9.5 \%$, $9 \%, 0 \%, 6.1 \%, 4.5 \%, 3.3 \%$ and $1.7 \%$ respectively. Our proposal is based on the principle of special differential treatment and, to our knowledge, suggests the first time the use of distortionary support for West and Central African countries [8]. The quantification of impacts according to the criterion of equity is a novelty, compared to the previously analyzes.

The results of our study regarding the effects of full liberalization on world cotton market prices of $12.3 \%$ are in line with those of Daniel Sumner which found 12.6\% [9]. We have found that, the full trade liberalization is beneficial for all countries in terms of welfare except Developing countries. This result is similar than those of Antoine Bouët and David Laborde who show that full trade liberalization is beneficial for all regions in terms of representative agent's welfare and GDP, except Sub-Saharan Africa which is affected by an erosion of trade preferences (deterioration of terms of trade) [10]. This result is intuitive, because the higher the amount of distorting support, the greater the effects of full liberalization 
on the world price.

Our results show that the recent proposals of the Doha Round negotiations, except for the Falconner 2008 proposal, are more equitable than those of the Uruguay Round agreements. The Uruguay Agreements did not contain any explicit principle of equity. The Uruguay Round agreements have had very limited benefits for developing countries, which have accepted a wide range of obligations and responsibilities. The Uruguay Round agreement has only benefited developed countries at the expense of developing and least developed countries [11]. For Kouwoaye, GATT/WTO membership and trade liberalization more generally make winners and losers. It matters little to losers whether aggregate gains exceed losses if their real wage is never to recover. Better adjustment policies and "safety nets" must be designed to insure that as many people as possible benefit from policy reforms and to avoid that the poorest become even poorer [12].

Our results have shown that liberalization is beneficial for countries that trade with each other and are in line with other studies on the effects of agricultural agreements within the WTO [12]. Kym Anderson and Will Martin have shown, using the World Bank's LINKAGE model, that trade liberalization in the Doha Round generates annual gains of US \$300 billion per year, with a significant share of the gains going to developing countries (Sub-Saharan Africa and South Asia) [13].

Our proposal is a compromise between the USA and the C4 group, which makes it possible to reduce the level of reduction in US domestic support and to allow West African countries to grant support to their cotton producers. These supports granted come from the economies of developed countries on the reduction of supports. Countries must be urged to contribute to a complementary development aid fund from savings made in reducing amber box support. The results of our study cover a wide range of possible scenarios, not limited to the strict respect of reciprocity against developing countries [14]. NGUYEN and al have shown with a computable general equilibrium model that the gains from liberalization for some large nations, particularly the USA, are low or even negative in a context of imperfect competition [15]. ACHARYA and SOLOMON have shown that trade liberalization generates gains that do not benefit the poor in South Asia [16]. Rational states use protectionist measures for the well-being of their peoples [17]. There is a correlation between economic development and the level of protection measures in the agricultural sector. Kym Anderson and al have shown that the effects of liberalization are mixed between and even within groups of countries [18]. Liberalization can worsen the situation in some countries [19].

Our result show that total liberalization is good for all countries in terms of equity. For Ian and al, the underlying economic logic of the GATT/WTO is still relevant, but that enforcement of the cooperative agreement will likely be placed under significant strain with threat of increased protection, and even a potential trade war [20].

One of the possible limitations of our analysis is the quality of the data. We have used the notifications of the various States to the WTO, these notifications do not always correspond to the actual level of support from the countries. As proof, some US distorting measures have been classified in the green box even though they have been declared by the WTO Dispute Settlement Body as distorting measures in the dispute between the US and Brazil. The model does not capture the effects of the blue box measurements, which are partially decoupled. A more refined model should capture the effects of Blue Box measures that are increasingly being challenged by some WTO member countries.

\section{Conclusion}

The Doha Development Round is blocked on agriculture and especially on the cotton issue. Our study analyzes the effects of six scenarios, with an additional scenario with consideration of the principle of special and differential treatment.

Given the traditional criteria of impacts on prices, volumes and welfare, the status quo is detrimental for all countries. The total liberalization beyond being unrealistic for the moment, induces a global price increase of $12.3 \%$. Comparatively, the EU proposal, the Falconner proposal, the USA proposal, and the $\mathrm{C} 4$ countries proposals increase the world price by $3.3 \%, 4.5 \%, 6.1 \%, 9.0 \%$ respectively. Our proposal is a good compromise to conclude the Doha Round, with increased benefits for developing countries and the most favoring producer price $(10.8 \%)$.

In terms of equity criteria, total liberalization is the most equitable. The recent proposals of the Doha Round negotiations, except for the Falconner 2008 proposal, are more equitable than those of the Uruguay Round Agreements.

\section{References}

[1] Jason H. Grant and Kathryn A. Boys, Agricultural Trade and the GATT/WTO: Does Membership Make a Difference? American Journal of Agricultural Economics. Vol. 94, No. (1), 2011, pp. 1-24. doi: 10.1093/ajae/aar087\% J American Journal of Agricultural Economics.

[2] Tadash IIto and Takahide Aoyagi, Did the least developed countries benefit from duty-free quota-free access to the Japanese market? Japan and the World Economy. Vol. 49, No. (2), 2019, pp. 32-39. doi: https://doi.org/10.1016/j.japwor.2018.09.002.

[3] Bader Bakhit M. AlModarra, Defining the Contours of the Public Morals Exception under Article XX of the GATT 1994 Journal of International Law and Trade Policy. Vol. 18, No. (2), 2017, pp. doi: https://ageconsearch.umn.edu/record/268478.

[4] Ralf Peters and David Vanzetti, User manual and handbook on Agricultural Trade Policy Simulation Model (ATPSM). Policy issues in international trade and commodities, no. 24. New York: United Nations. 2004, 55.

[5] J. Stacy Adams, Toward an understanding of inequity. Journal of Abnormal and, Social Psychology. Vol. 67, No. (5), 1963, pp. 422-436. 
[6] G. Akerlof and J. Yellen, The Fair Wage-Effort Hypothesis and Unemployment The Quaterly Journal of Economics. Vol. 105, No. (2), 1990, pp. 255-283.

[7] George A. Akerlof, Explorations in Pragmatic Economics, ed. OXFORD. 2005.

[8] Cheung Chai Hong, A Study on the Legal Issues Arising from the Investigation on Various Industrial Impacts of Trade in Services Outside of the WTO Framework. Social Sciences. Vol. 7, No. (2), 2018, pp. 88-93. doi: 10.11648/j.ss.20180702.16.

[9] Daniel A. Sumner, A quantitative simulation analysis of the impacts of $u$. s. cotton subsidies on cotton prices and quantities. 2003. p. 50.

[10] Antoine Bouët and David Laborde, Plurilateral agreements: a promising trade liberalization modality? Presented at the 22nd Annual Conference on Global Economic Analysis, Warsaw, Poland). Purdue University, West Lafayette, IN: Global Trade Analysis Project (GTAP). Retrieved from Vol. No., 2019, pp. doi:

https://www.gtap.agecon.purdue.edu/resources/res_display.as $\mathrm{p}$ ?RecordID $=5878$.

[11] Dinesh Marothia, Will Martin, A. Janaiah, and C. L. Dadhich, WTO and Domestic Support under USA Farm Act 2014: Implications for Developing Countries in the IAAE-ISAE Inter-Conference Symposium on Re-visiting Agricultural Policies in the Light of Globalisation Experience: The Indian Context. 2016: India.

[12] Kouwoaye Amevi Rocard, Is GATT/WTO Membership Decreasing Poverty in Developing Countries?, in the 7th Annual Canadian Agri-Food Policy Conference,. 2017: Ottawa, Ontario. p. 2.

[13] Kym Anderson and Will Martin, Agricultural Trade Reform and the Doha Development Agenda. The World Economy. Vol. 28, No. (9), 2005, pp. 1301-1327.
[14] Michael Friis Jensen, African Demands for Special and Differential Treatment in the Doha Round: An Assessment and Analysis. Development Policy Review. Vol. 25, No. (1), 2007, pp. 91-112. doi: 10.1111/j.1467-7679.2007.00361.x.

[15] Sachin Kumar Sharma, WTO and policy space for agriculture and food security: issues for China and India. Agricultural Economics Research Review. Vol. 31, No. (2), 2018, pp. $207-$ 219. doi: 10.5958/0974-0279.2018.00038.1.

[16] Sanjaya Acharya and Solomon Cohen, Trade liberalisation and household welfare in Nepal. Journal of Policy Modeling. Vol. 30, No. (6), 2008, pp. 1057-1060.

[17] Johan F. M. Swinnen, A Positive Theory of Agricultural Protection. American Journal of Agricultural Economics. Vol. 76, No. (1), 1994, pp. 1-14.

[18] Kym Anderson, WILL Martin, and Dominique Van Der Mensbrugghe, Distortions to World Trade: Impacts on Agricultural Markets and Farm Incomes. Review of Agricultural Economics. Vol. 28, No. (2), 2006, pp. 168-194. doi: $10.1111 /$ j.1467-9353.2006.00280.x.

[19] Popat Meizal, Griffith Garry, and Mounter Stuart, The Economic Impact of Imports on the Australian Pig Industry: Is it Time for the WTO's Safeguard Measures? 1. Replicating and Updating the 2008 Productivity Commission Analyses. Australian Agribusiness Review. Vol. 25, No., 2017, pp. 20.

[20] Ian M. Sheldon, Daniel C. K. Chow, and William McGuire, Trade Liberalization and Institutional Constraints on Moves to Protectionism: Multilateralism vs. Regionalism, in 2018 Annual Meeting of the Allied Social Sciences Association (ASSA), January 5-7, 2018. 2017: Philadelphia, PA. p. 32. 